\title{
Forkhead Box Protein P1
}

National Cancer Institute

\section{Source}

National Cancer Institute. Forkhead Box Protein P1. NCI Thesaurus. Code C97551.

Forkhead box protein P1 (677 aa, $75 \mathrm{kDa}$ ) is encoded by the human FOXP1 gene. This protein is involved in transcriptional repression. 